\title{
Case Based Approach in Pharmacology: A Novel Approach
}

\author{
Banerjee $\mathrm{I}^{1}$
}

${ }^{1}$ Lecturer, Department of Pharmacology, Manipal College of Medical Sciences, Pokhara, Nepal

Chief Editor

Dr. Brijesh Sathian

Technical Editor

Dr. Nishida Chandrasekharan

Formatting Editor

Dr. Ram Lakhan

\section{embase BIOMEDICAL ANSWERS}

This title is indexed in SciVerse Scopus

Improving research results through analytical power

\section{Editorial}

\section{Corresponding Author:}

Dr. Indrajit Banerjee MD

Lecturer, Department of Pharmacology,

Manipal College of Medical Sciences, Pokhara, Nepal

E-mail: indrajit18@gmail.com

Manipal College of Medical Sciences (MCOMS), Pokhara which is the first private medical college of Nepal established on $1994^{1}$. It is affiliated to Kathmandu University. Students from Nepal, Srilanka, Bangladesh, India, Canada, USA and Africa studies at this esteemed institution ${ }^{2}$. The author has joined MCOMS on 2008 as a MD Pharmacology resident and is actively involved in teaching and learning process of Pharmacology. He is the first MD in Pharmacology under Kathmandu University from Nepal. The author has also completed MBBS from the same institution 3,4

In Nepal MBBS is an integrated course for four and half years. Pharmacology is taught in the first two years viz. first four semesters ${ }^{5,6,7}$. Often a student finds Pharmacology as a dry and boring subject. They find it difficult to remember the name of the drugs. So often they neglect and find it less interesting as compared to the other subjects of Basic Sciences. One of the major drawbacks a student faces is that they are not acquainted with the hospital and they don't see patient. In a simplified way pharmacology is a subject that deals with the drug. But ultimately the drug has to be used in the patient.

According to the present Kathmandu University curriculum student has to study General Pharmacology, Autonomic Nervous System, Integumentary system, Musculoskeletal system, Respiratory system and Cardiovascular system in the first year. In the second year they has to study Gastrointestinal system, Renal System, Endocrine, Reproductive, Miscellaneous topics and Central Nervous system. According to the new curriculum the exam pattern has also changed at Manipal College of medical college. Currently there are multiple choice question, problem based question and short answer question pattern followed in the examinations. I have found in my past 6 yrs of teaching pharmacology ${ }^{8}$ that case oriented approach of teaching pharmacology is a very good method in teaching pharmacology and it is a novel approach in Nepal. Southern Illinois University School of Medicine, United States has shown that case oriented approach is a good technique of the medical education ${ }^{9}$.

Some of the examples of case oriented approach in Pharmacology have been discussed in this paper.

\section{\# CASE 1: ANS- Reversible Anti cholinesterse drugs}

Miss X, 18/female from Arwa, Kaski was brought to Manipal Teaching Hospital ${ }^{10}$ on 12.1.2011 with a history of consumption of half a bottle of (Metacid) Insecticides after failing in the SLC (Class 10) Examination.

\#History of Presenting Illness

She has a history of ingestion of half a bottle of Poison. After that she has vomiting of 6 episodes and also Urination, Salivation, Diarrhoea were Positive. There were no h/OSeizure, Respiratory \& Cardiac Depression . \#On Examination \# GCS-10/15, Pulse-60/min, RR-32/min, BP-90/60 mm Of $\mathrm{Hg}$, Spo2-70\% Without O2.Pallor, Icterus, Cyanosis, Clubbing, Lymphadenopathy and Edema were negative. 
(PICCLE)

\#Systemic Examination

Cardiovascular System(CVS)-S1S2M0

Respiratory System-Bilateral [B/L] occational crepitation present

Per Abdomen (P/A)-Soft, No Organomegaly

CNS-Pupils-B/L constricted( Bilaterally)

Power-4/5[Upper \& Lower Limb]

\#Investigations

Serum Cholinesterase-750 U/L (Normal Value 35009000u/L)

Rbs-80mg\% [Normal Value 70-110mg\%]

\#Diagnosis-Organo phosphosphorous Poisoning

\#Treatment

$\mathrm{O}_{2}$ Inhalation

Activated Charcoal $-30 \mathrm{ml}$

Inj. Atropine( $0.6 \mathrm{mg} / \mathrm{ml}$ ) 3-10 Mg Every $10 \mathrm{~min}$ till signs of atropinization followed by a maintenance dose of $1-3 \mathrm{mg}$ $1 / 2$ hourly $^{11}$.

Inj.Pralidoxime $(500 \mathrm{mg} / 20 \mathrm{ml})-1 \mathrm{gm}$ In $100 \mathrm{ml}$ normal saline over 30 min every 4-6 hrly $^{11}$.

Patient was admitted in the ICU.

Discussion of Case 1: After the end of the case presentation students will understand the significance of organo phosphorous poisoning as the patient was admitted to Intensive care unit. Nepal is an agricultural country and it is a common problem in Nepal. They will some idea regarding the general and systemic examination of a case. They will know how a patient presents with organo phosphosphorous poisoning and what the treatment of the case is? How to come to the diagnosis of a case?. This is very important step because they are the future doctors they have to apply the things what they have learned in theory. After that the theoretical portion of irreversible anti cholinesterase drug can be taught. It will make the student more comfortable to understand the topic because they have got the clinical picture of the case in mind.

\section{\#CASE 2: Myocardial Infarction (MI)}

A 60 year old lady $Y$ was returning home after visiting hers friend's house suddenly she felt pain in the chest radiating to the left arm \& shoulder associated with sweating. She took 3 tabs of Nitroglycerine $0.5 \mathrm{mg}$ at an interval of 5 mins Pain did not get relieved

\#Investigations: The patient was brought to the emergency of Manipal Teaching Hospital and ECG was taken, which has showed ST segment elevation in the lead II, III, AVF. Cardiac EnzymesCK-MB, TROPONIN I \& T were elevated.

\#Diagnosis: She was diagnosed as a case of acute inferior wall myocardial infarction.

\#Treatment given:

1. Inj. Morphine $10 \mathrm{mg}$ stat

2. Inj. Promethazine $50 \mathrm{mg}$ IV stat

3. 02 Inhalation@ 4lt/min

4. Tab. Aspirin $300 \mathrm{mg}$ stat and $75 \mathrm{mg}$ daily

5. Tab. Clopidogrel $300 \mathrm{mg}$ stat and $75 \mathrm{mg}$ daily

6. Tab. Enalapril $5 \mathrm{mg} \times \mathrm{HS}$
7. Inj. Streptokinase 1.5 million units is given IV as an infusion over $60 \mathrm{~min}$.

8. Inj. Low Mol. Weight Heprin 5000 U Subcuteneous ODX 5 days

9. Tab. Atovastatin $20 \mathrm{mg} \times \mathrm{OD}$

10. Tab. Alprazolam $0.5 \mathrm{mg} \times \mathrm{HS}$

11. Tab. Isosorbide dinitrate $5 \mathrm{mg} \times \mathrm{BD}$

12. Syp. Cremaffin (Liquid Paraffin: $3.75 \mathrm{ml}$ and Milk of Magnesia $11.25 \mathrm{ml}) 15 \mathrm{ml}$ x HS

Patient was admitted to ICU of Manipal Teaching Hospital.

Discussion of case 2: At the end of the case present a student will understand how a case of MI presents and the severity of the case, patient have to be admitted to the ICU. What are the ECG changes and the biochemical markers? How to diagnose the case of MI? What is the difference with Angina Pectoris? What is the treatment of MI? Followed by the case presentation theoretical portion Myocardial infarction drugs can be taught. It will make the student more comfortable to understand the topic because they have got the clinical picture of the case in their mind.

\section{\#CASE 3: Peptic Ulcer}

Mr. X, 32 yrs smoker and alcoholic male from Pokhara came to the Medicine OPD of Manipal Teaching Hospital Pokhara with chief complaints of Epigastric pain for 3 weeks. Patient was asymptomatic 15 days back when he developed pain in the abdomen mainly in the epigastric region. Pain is more in empty stomach and relieved by taking food.

\section{On Examination}

\# Pulse-70/min, RR-16/min, BP-118/80 mm of Hg, Pallor, Icterus, Cyanosis, Clubbing, Lymphadenopathy and Edema were negative. On Local examination Tenderness were present in the epigastic region.

\# On Investigations

Barium meal study: Duodenal cap

Endoscopy reveals - An ulcer in the Duodenum

\# Diagnosis: Duodenal Ulcer

\# Treatment: $\quad$ Cap Amoxycillin 1000 mg BD $\times 2$ Weeks

Tab. Clarithromycin $500 \mathrm{mg}$ BD $\times 2$ Weeks

Cap. Lansoprazole $30 \mathrm{mg}$ BD x2 Weeks

Discussion of Case 3: At the end of the case presentation a student will learn that how a patient presents with Duodenal Ulcer. What are the investigations done? How to come to the diagnosis of Peptic Ulcer? What is the treatment of the case? They will learn the integration between different subjects. They will get the clinical picture in their mind before starting with the details of the drugs used for the peptic ulcer disease.

\section{\#Case 4: Seizure disorder/ Epilepsy}

Mrs. Y a 43 yrs old lady from Tanahun, Nepal came to the emergency of Manipal Teaching Hosptal with chief complaints of abnormal body movement for 5 days. The Patient was asymptomatic 5 days back when she developed abnormal body movement. Patient reported 
that it started from Left arm and was associated with stiffness of all limbs Jerky movement and frothing from the mouth was present. Post ictal period was normal. There was no history of headache. She had a past history of similar arrack 2 yrs ago.

\section{\# On Examination}

Vital signs- Pulse-68/min, BP-120/80, RR-16/min, T-98.6-F Systemic Examination: CVS-S1S2Mo, R/S-NVBS, B/L air entry equal, P/A-NAD, CNS-Reflex -Brisk

\#Investigations:

$\mathrm{Na}+134 \mathrm{meq} / \mathrm{L}, \mathrm{K}+-3.9 \mathrm{meq} / \mathrm{L}$. CT Scan HeadNeurocystocercosis

\# Diagnosis: Seizure disorder due to Neurocystocercosis \#Treatment: Tab.Phenytoin 300 mg Night time

Tab.Carbamazepine 200 mg 1-0-2

Tab Albendazole 400 mg BD X 28 days

Tab Prednisolone 30 mg BDX 14 Days

$$
\begin{aligned}
& 20 \mathrm{mg} \times 7 \text { days } \\
& 10 \mathrm{mg} \times 7 \text { days } \\
& 5 \mathrm{mg} \times 3 \text { days \& stop }
\end{aligned}
$$

Discussion Case 4: This is a complicated case but at the end of the case presentation student will know that how a seizure disorder patient presents with. When the case was investigated properly the patient was diagnosed as a case of Neurocystocercosis. Neurocystocercosis is a common problem in context to the Nepalese population. They will be able to diagnose the case. What is the treatment of the case? Why Albendazole was used in this case? Why prednisolone dose is tapperd? It will be easier for a student to understand the drugs if they will be having the clinical picture in their mind.

\section{\# Case 5: Pulmonary Tuberculosis.}

Mr.X, 46 yrs male from Nayapul, Kaski came to the medicine OPD of Manipal Teaching Hospital on $4^{\text {th }}$ June 2013 with chief complaints of hemoptysis, cough, fever for 3 weeks. Fever was mainly seen in the evening time and he also complains of loss of weight and appetite. Mr.X is a known case of smoker for 15 yrs.

- On Examination: Pallor, Icterus, Cyanosis, Clubbing, and Edema were negative. Lymphadenopathy Positive

- $\quad$ P- 86/min

- $\quad$ BP- $100 / 68 \mathrm{~mm}$ of $\mathrm{Hg}$

- $\quad$ RR- $22 / \mathrm{min}$

- $\mathrm{T}-100^{\circ} \mathrm{F}$

Investigations: On sputum examination Acid and alcohol fast bacilli is seen. Chest $x$ ray shows cavitation in the left lung.

Diagnosis: Category 1 Pulmonary Tuberculosis.

Treatment: 2 HRZE+ 4 HR

Initial Phase : ( 2 months)

Isoniazid $5 \mathrm{mg} / \mathrm{kg}$

Rifampicn $10 \mathrm{mg} / \mathrm{kg}$

Pyrizinamide- $20-30 \mathrm{mg} / \mathrm{kg}$
Ethambutol- $15-20 \mathrm{mg} / \mathrm{kg}$

Continuous phase( 4 months)

of Isoniazid $5 \mathrm{mg} / \mathrm{kg}$

Rifampicn $10 \mathrm{mg} / \mathrm{kg}$ from the DOTS centre

Discussion of Case 5: At the end of the case a student will know that how a case of pulmonary tuberculosis presents, what are the signs and symptoms, what are the different categories of treatment and common drugs used for the treatment of Tuberculosis at the beginning of the topic. They will get the clinical picture in their mind before starting with the details of the drugs used for the Pulmonary Tuberculosis.

\# Case 6: Leprosy

\# Mr. X,42 yr old male from Tatopani, Nepal came to Green Pastures Hospital, Dermatology OPD , Pokhara on 20/7/2012 with a history of having Hypopigmented patches and Loss of Cutaneous Sensation in the thigh for 3 Months

\# On Examination:

Vital Signs: NORMAL

PICCLE-NEGATIVE

Systemic Examination:

CVS: No abnormality was detected

R/S: No abnormality was detected

$\mathrm{P} / \mathrm{A}$ : No abnormality was detected

CNS No abnormality was detected

Skin:

Multiple Hypopigmented Patch:+++

Anaesthetic Patch :+++

Peripheral Nerves: Thickened

Ulnar Nerve :+++

Medial Nerve :+++

Common Peroneal Nerve:++++

Radial Nerve:+

\#Investigations:

Z-N staining:acid \& alcohol fast bacilli +++

Bacterological Index: 2.5

\#Diagnosis: lepromatous leprosy

\#Patient was admitted to green pastures hospital

\#Treatment

Dapsone $-100 \mathrm{mg} /$ day self administered

Rifampicin-600mg/month supervised dose

Clofazimine-50 mg/day self administered \& $300 \mathrm{mg} / \mathrm{month}$ supervised dose

\#Duration of therapy -12 months

Discussion of Case 6: At the end of the case a student will know what are the signs and symptoms of leprosy. What are the types of leprosy. How to come to the diagnosis of Leprosy? Student will learn the treatment of leprosy in an integrated manner at the beginning of the antilepromatic drugs.

Case 7: \# Urinary tract infection with Pregnancy

Mrs Z, 27 yrs old Female from Naudanda, Kaski came to the OBG OPD with chief complaints of Burning micturation 
and fever for 3 Days

History of presenting illness: Patient was asymptomatic 3 days back. She came for $1^{\text {st }}$ antenatal visit

History of pregnancy:Primipara , Period of Gestation 12 wks.

\#On Examination

P+ I- C- C- L-E-

Vital Signs:

P-68/min

BP-110/90 $\mathrm{mm}$ of $\mathrm{Hg}$

$\mathrm{T}-100^{\circ} \mathrm{F}$

$\mathrm{RR}-16 / \mathrm{min}$

\#Systemic Examination

CVS-S1 S2 Mo

R/S-NVBS B/L air entry equal

$\mathrm{P} / \mathrm{A}$-Soft, No organomegaly

CNS-WNL

\#Investigations:

UPT- Positive ( Urine Pregnancy TesT)

Urine R/E- pus cells positive, no RBC'S present

Urine $\mathrm{C} / \mathrm{S}$ - Presence of E.coli Bacteria

$>10^{5}$ bacteria/ml

Resistance to Amoxycillin

\#Diagnosis: Pregnancy with Urinary tract infection

\# Treatment : Cap:Cephalexin 250 mg QIDX 5 days

\#Advice : Drink plenty of water

\#Patient was admitted in OBG ward

Discussion of Case7: At the end of the case a student will know what are the clinical features of urinary tract infection? How to come to the diagnosis of Urinary tract infection? What are the treatment modalities available if the patient is pregnant? They will get a clinical picture in mind before studying about the drugs used for UTI.

\section{\# Case 8: Malaria}

Mr. X, 47 years /Male from Ghandruk came to Manipal Teaching hospital on 15/9/2013 with symptoms of relapsing fever with chills repeating on every third day, Headache

bodyache and myalgia.

\section{On examination}

Vital signs

Temperature: 103 degrees F, Respiratory rate: 20/min, Pulse rate: 100/min, Blood ressure: Normal(120/80mm Hg)

Pallor - positive (pale eyes), Icterus-Negative, CyanosisNegative, Clubbing -Negative, Lymphadenopathy-Negative, Edema-Negative

Systemic Examination

CVS-S1 S2 Mo

R/S-NVBS B/L air entry equal

$\mathrm{P} / \mathrm{A}$ - Hepatosplenomegaly present

CNS-WNL

Investigations

On peripheral blood smear: Trophozoites of Plasmodium vivax was Seen

Diagnosis: benign tertian malaria
Patient was admitted to MTH

Treatment: Chloroquine phosphate $1000 \mathrm{mg}=600 \mathrm{mg}$ (BASE) then $500 \mathrm{mg}-300 \mathrm{mg}$ (BASE) after $6 \mathrm{hrs}$. followed by $500 \mathrm{mg}$ 300mg (BASE) daily for two days.

Primaquine26 mg-15mg (BASE) for 14 days

Patient was discharged with no complications after 7days

Discussion of Case 8: At the end of the case a student will know clinical aspects of Malaria. What are the clinical features, investigations and treatment of malaria? So the students will feel more interest while studying about the anti malarial drugs.

\# Case 9: Morphine Poisoning (Drug Abuse)

Dr. X , 24 yrs, Intern (Doctor) from Pokhara came to ER of MTH with Chief complaints of Loss of consciousness for $\mathbf{3 0}$ $\min$.

History of presenting illness

Dr. $X$ was found unconscious in the Doctor's room of $X Y Z$ Emergency

He was on night duty at the Emergency Department of $X Y Z$ Hospital.

On Examination

PICLE- Negative

Cyanosis-Positive

Vital Signs

Pulse-56 bpm

RR-12/min

BP-90/56mm of $\mathrm{Hg}$

Temperature- $\left(96.2^{\circ} \mathrm{F}\right)$

Systemic Examination

CVS- S1S2Mo

RS- B/L NVBS ++

PA-WNL

CNS- Pupils constricted B/L

-Sensory \& Motor System intact

Local Examination

Multiple Prick mark (seven)in his hand, forearm present B/L

(Bi lateral)

Diagnosis: Acute Morphine poisoning (Drug Abuse)

\#Treatment:

Hospitalization

Maintain Airway Breathing Circulation (ABC)

Ventilatory support

Gastric lavage (Potassium permanganate)

Specific antidote- Inj. Naloxone $0.4-0.8 \mathrm{mg}$ IV, dose is repeated till respiration is normal

Discharges on oral Methadone $5 \mathrm{mg}$ after psychotherapy

Discussion of Case 9: At the end of the case a student will know about the drug abuse clnical aspects. The diagnosis and treatment of morphine poisoning. They will have more interest while studying about the drug abuse in respect to Pharmacology.

\#Case 10 Parkinsonism

Mr. X, 52 yrs male from Mahendrapool, Pokhara came to the medicine OPD of Manipal Teaching Hospital on $4^{\text {th }}$ June 
2013 with chief complaints of tremor, rigidity in the upper limb and abnormal gait for 6 weeks. On examination it was found by the clinician that there is course tremor and cog wheel rigidity on the upper limb. There was also postural instability and mask like face.

Diagnosis: Parkinson's disease.

Treatment:

Tab Levodopa + Carbidopa 100mg + 25 mg BDX 1 month Discussion of Case 10: At the end of the case presentation a student will know the common clinical features of Parkinsonism. They will how to diagnose and treat the disease. They will get a clinical picture in their mind before studying about the different drugs used for Parkinsonism in related to Pharmacology in details.

Similar case approach has been described by Sweetser $\mathrm{S}^{12}$. Case Oriented approach in Pharmacology will be helpful to know/study all the basic science in an integrated manner. This approach is a better approach so that the medical student will get the clinical scenario in the beginning of the topic. It will be also be effective tool for the students to solve the problem based questions and also they will learn the role of the clinical pharmacology too. Thus case oriented approach in teaching pharmacology will make Pharmacology more interesting subject. Recently based on certain evidences it was found out that basic science medical curriculum is based on clinical approach in which pharmacology is one integrated component in a holistic approach to teaching and learning methodology ${ }^{13}$.

One major problem of teaching pharmacology is that a student doesn't see patients in basic science teaching and learning method. This problem can be solved to some extent by this novel case oriented approach in Pharmacology.

\section{Acknowledgment}

I extend my heartfelt and cordial gratitude to Late Dr. Akhilesh Chandra Jauhari for all his guidance.

\section{References}

1. Banerjee I, Jauhari CA, Johorey CA, Gyawali S, Saha A. Student's Accreditation of integrated Medical Education in Nepal. Asian Journal of Medical Sciences 2011;2 (1): 49-52. http://dx.doi.org/10.3126/ajms.v2i1.3592

2. Banerjee I, Jauhari A C, Bista D, Johorey A C, Roy B and Sathian B, Medical Students View about the Integrated MBBS Course: A Questionnaire Based Cross-sectional Survey from a Medical College of Kathmandu Valley, Nepal Journal of Epidemiology 2011;1(3): 95-100. http://dx.doi.org/10.3126/nje.v1i3.5575

3. Banerjee I. Teaching Communication Skills: A five year experience from a private medical school of Nepal. Medical Science 2013; 1(1): 12-14.

4. Shankar PR. Seven years' experience of P-drug selection. AMJ.2011, 4, 4, 201-204. http://dx.doi.org/10.4066/AMJ.2011.648

\section{PMid:23393511 PMCid:PMC3562898}

5. Banerjee I, Roy B, Sathian B, Banerjee I, Kumar SS, Saha A. Medications for Anxiety: A Drug utilization study in Psychiatry Inpatients from a Tertiary Care Centre of Western Nepal. Nepal Journal of Epidemiology 2010; 1(4):119-25.

http://dx.doi.org/10.3126/nje.v1i4.5753

6. Banerjee I, Roy B, Pugazhandhi B, Sathian B, Saha A, Banerjee I. Teaching aids in Pharmacology teaching and learning methodology: A study from a private medical college of Nepal. International Journal of Interdisciplinary and Multidisciplinary Studies, 2013, Vol 1, No.1, 1-7.

7. Banerjee I, Roy B, Banerjee I, Sathian B, Mondol M, Saha A. Depression and its Cure: A Drug Utilization Study from a Tertiary Care Centre of Western Nepal. Nepal Journal of Epidemiology 2011; http://dx.doi.org/10.3126/nje.v1i5.6152

$1(5): 144-52$.

8. Banerjee I. Concepts of P Drug Selection. Nepal Journal of Epidemiology 2013;3 (1): 226-229. http://dx.doi.org/10.3126/nje.v3i1.8280

9. Clough RW1, Shea SL, Hamilton WR, Estavillo JA, Rupp G, Browning RA, Lal S.Weaving basic and social sciences into a case-based, clinically oriented medical curriculum: one school's approach. Acad Med. 2004 Nov;79(11):1073-83. http://dx.doi.org/10.1097/00001888-200411000-00013 PMid:15504774

10. Banerjee I, Roy B, Sathian B, Banerjee I, Chakraborty PK, Saha A. Socio demographic profile and utilization pattern of antipsychotic drugs among schizophrenic inpatients: a cross sectional study from western region of Nepal. BMC $\begin{array}{llll}\text { Psychiatry. } & 2013 \quad \text { Mar 22;13:96. }\end{array}$ http://dx.doi.org/10.1186/1471-244X-13-96 PMid:23522357

11. Wadia R S. Treatment of Organophosphate Poisoning. Indian J Crit Care Med 2003;7:85-7

12. Sweetser S. Evaluating the patient with diarrhea: a case-based approach. Mayo Clin Proc. 2012 Jun;87(6):596602.

http://dx.doi.org/10.1016/j.mayocp.2012.02.015 PMid:22677080 PMCid:PMC3538472

13. Kwan CY. Learning of medical pharmacology via innovation: a personal experience at McMaster and in Asia.Acta Pharmacol Sin. 2004 Sep;25(9):1186-94. PMid:15339396

\begin{tabular}{|l|l|}
\hline \multicolumn{2}{|c|}{ Article Information } \\
\hline \multicolumn{2}{|c|}{ Article history } \\
\hline Received & $1^{\text {st }}$ January 2014 \\
\hline Received in revised form & $28^{\text {th }}$ February 2014 \\
\hline Accepted & $5^{\text {th }}$ March 2014 \\
\hline
\end{tabular}

